\title{
Pseudonocardia endophytica sp. nov., isolated from the pharmaceutical plant Lobelia clavata
}

\author{
Correspondence \\ Wen-Jun Li \\ wjli@ynu.edu.cn \\ or \\ liact@hotmail.com
}

\author{
Hua-Hong Chen, ${ }^{1,2}$ Sheng Oin, ${ }^{1}$ Jie Li, ${ }^{1}$ Yu-Oin Zhang, ${ }^{3}$ Li-Hua Xu, ${ }^{1}$ \\ Cheng-Lin Jiang, ${ }^{1}$ Chang-Jin $\mathrm{Kim}^{4}$ and Wen-Jun $\mathrm{Li}^{1}$
}

\author{
${ }^{1}$ The Key Laboratory for Microbial Resources of the Ministry of Education, PR China, and \\ Laboratory for Conservation and Utilization of Bio-Resources, Yunnan Institute of Microbiology, \\ Yunnan University, Kunming, Yunnan 650091, PR China \\ ${ }^{2}$ Department of Chemistry and Biology, Chuxiong Normal University, Chuxiong, Yunnan 675000, \\ PR China \\ ${ }^{3}$ Institute of Medicinal Biotechnology, Chinese Academy of Medical Sciences \& Peking Union \\ Medical College, Beijing 100050, PR China \\ ${ }^{4}$ Functional Metabolomics Research Center, KRIBB, Daejeon 305-806, Republic of Korea
}

There are many endophytic micro-organisms inside healthy tissues of nearly all living plants, and endophytes are important sources of bioactive metabolites (Strobel et al., 2004; Sardi et al., 1992). Actinomycetes have been isolated from the stem and root interior of many plants species (de Araújo et al., 2000; Coombs \& Franco, 2003; Okazaki et al., 1995). The genus Pseudonocardia was originally proposed by Henssen (1957) for mycolateless, nocardioform actinomycetes with a type IV cell wall (Lechevalier \& Lechevalier, 1970), and its description has been emended by Warwick et al. (1994), McVeigh et al. (1994), Reichert et al. (1998) and Huang et al. (2002). In the present study, an endophytic strain YIM $56035^{\mathrm{T}}$ was isolated from the inner tissue of Lobelia clavata. Polyphasic analysis demonstrated that the strain should be recognized

The GenBank/EMBL/DDBJ accession number for the 16S rRNA gene sequence of strain YIM $56035^{\top}$ is DQ887489.

An electron micrograph showing substrate mycelium of strain YIM $56035^{\top}$ is available as supplementary material with the online version of this paper. as a novel species of the genus Pseudonocardia, for which the name Pseudonocardia endophytica sp. nov. is proposed.

Strain YIM $56035^{\mathrm{T}}$ was isolated from the healthy inner tissue of $L$. clavata collected from Yunnan Province, southwestern China. L. clavata, a traditional Chinese medicinal plant, is usually used to treat parotitis and rheumatoid arthritis. Isolation of the strain was performed as follows: plant tissues (stems, leaves and roots) were washed thoroughly in running tap water to remove all soil, and these samples were surface sterilized by the method described by Shimizu et al. (2000). The surface-sterilization process was checked by rolling the surface-sterilized plant material aseptically onto the isolation medium, tap wateryeast extract agar (TWYE; Crawford et al., 1993), and a control medium, tryptic soy agar (TSA), and then incubating the plates at $28{ }^{\circ} \mathrm{C}$ for 7 days. No contamination was found. Surface-sterilized stems, leaves and roots were cut and placed in a sterilized commercial blender and then ground into small pieces and plated onto TWYE containing nalidixic acid $\left(10 \mathrm{mg} \mathrm{ml} \mathrm{ml}^{-1}\right)$, nystatin and cycloheximide (each at $50 \mathrm{mg} \mathrm{ml}^{-1}$ ) to repress growth of 
bacteria and fungi. Petri dishes were incubated at $28{ }^{\circ} \mathrm{C}$ for 4 weeks. Pure cultures were obtained by repeated streaking on plates that contained TWYE medium. Peptone-yeast extract-glycerol agar (PYGA; Martí et al., 1999) and TSA were used for cultivating the isolates. The selected isolate, YIM $56035^{\mathrm{T}}$, was maintained on slopes of TSA at $4{ }^{\circ} \mathrm{C}$ or room temperature. For long-term preservation, cells were stored as suspensions of mycelium fragments in $30 \%(\mathrm{v} / \mathrm{v})$ glycerol at -20 and $-80{ }^{\circ} \mathrm{C}$. Cell mass for chemical and molecular systematic studies was grown in shaken flasks (shaken at about 150 r.p.m.) of TSB (tryptic soy broth) at $28{ }^{\circ} \mathrm{C}$ for 10 days.

Extraction of genomic DNA, PCR amplification and sequencing of the 16S rRNA gene were performed as described by Li et al. (2007) and an almost-complete 16S rRNA gene sequence of strain YIM $56035^{\mathrm{T}}$ (1452 bp) was determined. Multiple sequence alignments were performed using CLUSTAL_X software (Thompson et al., 1997) and phylogenetic analysis was done with MEGA 3.1 (Kumar et al., 2004). A phylogenetic tree was constructed by the neighbour-joining method (Saitou \& Nei, 1987). Bootstrap values were determined using the method of Felsenstein (1985) with 1000 bootstrap resamplings. The 16S rRNA gene sequences analysis indicated that strain YIM $56035^{\mathrm{T}}$ belongs to the genus Pseudonocardia, and it was most closely related to Pseudonocardia kongjuensis LM $157^{\mathrm{T}}$ (98.5\% similarity), Pseudonocardia autotrophica IMSNU $20050^{\mathrm{T}}(97.3 \%)$, Pseudonocardia ammonioxydans $\mathrm{H}^{\mathrm{T}}$ (97.3\%) and Pseudonocardia compacta IMSNU $20111^{\mathrm{T}}$ (97.1\%) (Fig. 1); sequence similarities between strain YIM $56035^{\mathrm{T}}$ and other type strains of the genus Pseudonocardia were less than $97 \%$.

DNA-DNA hybridization was performed by using the fluorometric microwell method (Ezaki et al., 1989; Christensen et al., 2000; He et al., 2005). DNA-DNA relatedness values (means $\pm \mathrm{SD}, n=3$ ) between strain YIM $56035^{\mathrm{T}}$ and $P$. kongjuensis DSM 44525 $5^{\mathrm{T}}$, P. autotrophica DSM $535^{\mathrm{T}}, P$. ammonioxydans $\mathrm{H} 9^{\mathrm{T}}$ and $P$. compacta DSM $43592^{\mathrm{T}} \quad$ were $\quad 62.2 \pm 4.6, \quad 52.1 \pm 2.7, \quad 45 \pm 2.5 \quad$ and
$42.6 \pm 3.2 \%$, respectively. These values indicated clearly that strain YIM $56035^{\mathrm{T}}$ represents a distinct genomic species (Stackebrandt \& Goebel, 1994).

Amino acids and sugars of whole-cell hydrolysates were analysed as described previously (Hasegawa et al., 1983). Menaquinones were extracted according to the method of Collins (1985) and analysed by HPLC (Groth et al., 1997). Polar lipids were extracted and identified following the method of Minnikin et al. (1979) and Collins \& Jones (1980). The cellular fatty acids were determined according to the standard protocol of the MIDI/Hewlett Packard Microbial Identification System (Sasser, 1990). The G+C content of genomic DNA was determined by the HPLC method (Mesbah et al., 1989). The chemotaxonomic data match the description of the genus Pseudonocardia (Huang et al., 2002). Strain YIM $56035^{\mathrm{T}}$ had a type-IV cell wall composition, containing meso-diaminopimelic acid, arabinose and galactose (Lechevalier \& Lechevalier, 1970), which are common to members of the genus Pseudonocardia. The menaquinones were MK- $8\left(\mathrm{H}_{4}\right), \mathrm{MK}-7\left(\mathrm{H}_{6}\right)$ and MK-9 (ratio 97.5: 1.8:0.7); MK-8 $\left(\mathrm{H}_{4}\right)$ is the predominant menaquinone generally found in this genus. The phospholipids were phosphatidylethanolamine, phosphatidylcholine, phosphatidylmethylethanolamine and diphosphatidylglycerol (type PIII; Lechevalier et al., 1977; Lechevalier \& Lechevalier, 1980). The major fatty acids were $\mathrm{i}-\mathrm{C}_{16: 0}$ (34.03\%), $\mathrm{C}_{17: 1}$ cis $9(14.69 \%)$ and $\mathrm{i}-\mathrm{C}_{15: 0}(9.62 \%)$ (Table 1). Phospholipid type III and the presence of $\mathrm{i}-\mathrm{C}_{16: 0}$ as the major fatty acid are in agreement with the description of the genus Pseudonocardia (Huang et al., 2002). The DNA G +C content of strain YIM $56035^{\mathrm{T}}$ was $70.3 \mathrm{~mol} \%$, which is within the range of values for members of the genus Pseudonocardia (Huang et al., 2002).

Cultural characteristics were examined by incubating strain YIM $56035^{\mathrm{T}}$ at $28{ }^{\circ} \mathrm{C}$ on ISP media (Shirling \& Gottlieb, 1966) and the media described by Waksman (1961). Morphological characteristics of the strain were observed on ISP 2 medium (yeast extract/malt extract agar), PYGA and TSA after $7-14$ days at $28{ }^{\circ} \mathrm{C}$. Spores and mycelium

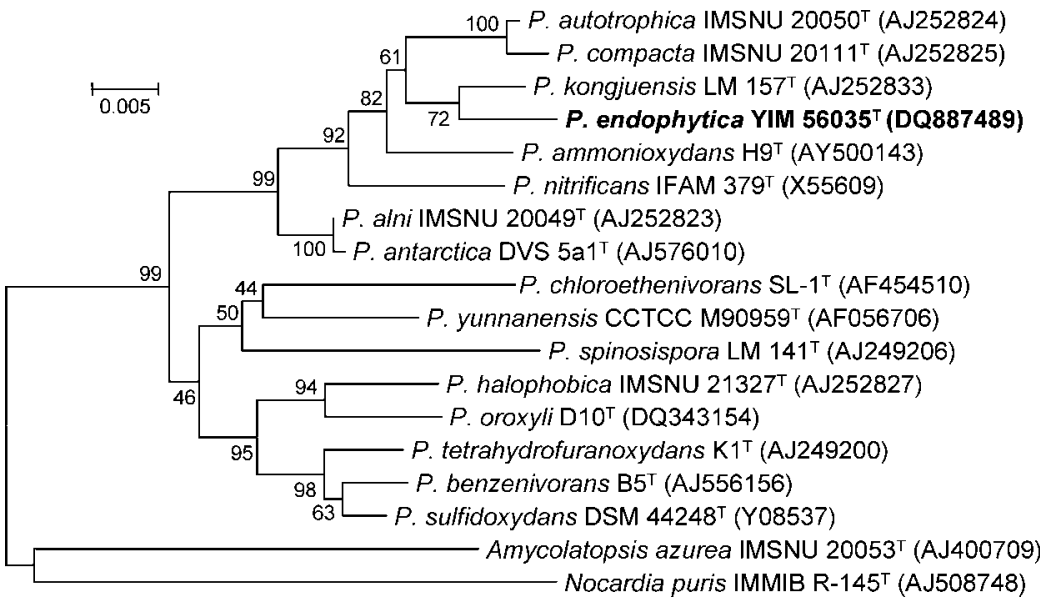

Fig. 1. Neighbour-joining phylogenetic dendrogram based on 16S rRNA gene sequences showing relationships between strain YIM $56035^{\top}$ and related representatives of Pseudonocardia. Numbers on branch nodes are bootstrap values (expressed as percentages of 1000 resamplings). The sequences of Amycolatopsis azurea IMSNU $20053^{\top}$ and Nocardia puris IMMIB R-145 ${ }^{\top}$ were used as the outgroup. Bar, 0.005 substitutions per nucleotide position. 
Table 1. Fatty acid contents (\%) of strain YIM $56035^{\top}$ and type strains of related Pseudonocardia species

Strains: 1 , strain YIM $56035^{\mathrm{T}} ; 2$, P. kongjuensis DSM $44525^{\mathrm{T}} ; 3, P$. ammonioxydans $\mathrm{H}^{\mathrm{T}} ; 4, \quad P$. autotrophica IMSNU20050 ${ }^{\mathrm{T}} ; 5, \quad P$. compacta IMSNU $20111^{\mathrm{T}}$. Data were obtained from this study under identical growth conditions. Only fatty acids making up more than $0.5 \%$ of the total are given. ND, Not detected.

\begin{tabular}{|c|c|c|c|c|c|}
\hline Component & 1 & 2 & 3 & 4 & 5 \\
\hline $\mathrm{i}-\mathrm{C}_{14: 0}$ & 1.20 & ND & ND & ND & ND \\
\hline $\mathrm{i}-\mathrm{C}_{15: 0}$ & 9.62 & 4.93 & 4.27 & 5.93 & 4.6 \\
\hline $\mathrm{i}-\mathrm{C}_{16: 0}$ & 34.03 & 28.39 & 50.01 & 38.42 & 34.22 \\
\hline $\mathrm{C}_{16: 1}$ cis 9 & 4.19 & 17.23 & 4.58 & 6.49 & 3.8 \\
\hline $\mathrm{i}-\mathrm{C}_{16: 1} \mathrm{H}$ & 4.19 & 3.72 & 13.46 & 16.23 & 4.2 \\
\hline $\mathrm{C}_{16: 0}$ & 2.00 & 6.19 & 1.63 & ND & ND \\
\hline $\mathrm{C}_{16: 0}$ 10-methyl & 4.68 & 4.63 & 5.63 & 9.35 & 4.81 \\
\hline $\mathrm{i}-\mathrm{C}_{17: 0}$ & 5.11 & 8.87 & 6.45 & 5.95 & 5.21 \\
\hline $\mathrm{C}_{17: 0}$ 10-methyl & 1.85 & 2.67 & 3.25 & 6.60 & 4.45 \\
\hline ai- $C_{17: 0}$ & 4.18 & 5.92 & 3.84 & 2.82 & 3.62 \\
\hline $\mathrm{C}_{17: 1}$ cis 9 & 14.69 & 12.91 & 5.10 & 8.21 & 18.6 \\
\hline $\mathrm{C}_{17: 0}$ & 3.89 & 2.41 & 1.78 & $\mathrm{ND}$ & ND \\
\hline $\mathrm{i}-\mathrm{C}_{18: 0}$ & 1.51 & $\mathrm{ND}$ & $\mathrm{ND}$ & $\mathrm{ND}$ & ND \\
\hline $\mathrm{C}_{18: 1}$ cis 9 & 2.19 & 2.14 & $\mathrm{ND}$ & $\mathrm{ND}$ & ND \\
\hline $\mathrm{C}_{18: 0}$ & 0.98 & $\mathrm{ND}$ & ND & ND & ND \\
\hline
\end{tabular}

were observed by light microscopy (Olympus microscope BH-2) and scanning electron microscopy (Philip XL30 ESEM-TMP). Growth at different temperatures $(4,10,15$, $20,28,37,40,45$ and $\left.55{ }^{\circ} \mathrm{C}\right), \mathrm{NaCl}$ concentrations $(0,1,3$, $5,7,10,15$ and $20 \%)$ and $\mathrm{pH}$ values $(\mathrm{pH} 5.0-10.0)$ was assessed on TSA, with reference type strains in parallel. Other physiological and biochemical tests were carried out as described previously (Gordon et al., 1974; Reichert et al., 1998; Liu et al., 2006).

Strain YIM $56035^{\mathrm{T}}$ had morphological properties typical of the genus Pseudonocardia. The aerial mycelium was white and the substrate mycelium was yellowish brown on TSA and ISP2 medium. No diffusible pigment was produced. Spore chains were borne at the ends of branched aerial hyphae, and the spore surface was smooth. The substrate mycelium fragmented into rod-shaped elements on TSA (Supplementary Fig. S1, available in IJSEM Online). Growth was observed at $15-37^{\circ} \mathrm{C}, 0-5 \% \mathrm{NaCl}(\mathrm{w} / \mathrm{v})$ and $\mathrm{pH} 6-8$. The optimal growth $\mathrm{pH}$, temperature and $\mathrm{NaCl}$ concentration were $\mathrm{pH} 7.0,28{ }^{\circ} \mathrm{C}$ and $1 \%$.

A range of phenotypic properties separated strain YIM $56035^{\mathrm{T}}$ from the type strains of species of Pseudonocardia with validly published names (Tables 1 and 2). Strain YIM $56035^{\mathrm{T}}$ can be differentiated from related Pseudonocardia species by the absence of phosphatidylglycerol and phosphatidylinositol. The isolate was distinguished from previously described species by the proportions of the major fatty acids $\left(\mathrm{i}-\mathrm{C}_{16: 0}, \mathrm{C}_{16: 1}\right.$ cis $9, \mathrm{i}-\mathrm{C}_{16: 1} \mathrm{H}$ and $\mathrm{C}_{17: 1}$ cis 9 ) and by the presence or absence of several fatty acids, including $\mathrm{i}-\mathrm{C}_{14: 0}, \mathrm{i}-\mathrm{C}_{18: 0}, \mathrm{C}_{18: 1}$ cis 9 and $\mathrm{C}_{18: 0}$ (Table 1).
Table 2. Differential characteristics of strain YIM $56035^{\top}$ and type strains of closely related Pseudonocardia species

Strains: 1 , strain YIM $56035^{\mathrm{T}} ; 2$, P. kongjuensis DSM $44525^{\mathrm{T}}$ (data from this study); 3, P. ammonioxydans $\mathrm{H}^{\mathrm{T}}$ (unless indicated otherwise, data from Liu et al., 2006); 4, P. autotrophica IMSNU $20050^{\mathrm{T}}$ (Lee et al., 2001); 5, P. compacta IMSNU 20111 ${ }^{\mathrm{T}}$ (Lee et al., 2001); +, Positive or present; $\mathrm{W}$, weakly positive; - , negative or absent; ND, no data available/not done. Data obtained during this study were obtained under identical growth conditions.

\begin{tabular}{|c|c|c|c|c|c|}
\hline Characteristic & 1 & 2 & 3 & 4 & 5 \\
\hline \multicolumn{6}{|l|}{ Acid production from: } \\
\hline Adonitol & - & + & + & + & - \\
\hline L-Arabinose & - & - & + & + & - \\
\hline Cellobiose & - & - & - & + & + \\
\hline meso-Erythritol & + & - & ND & - & - \\
\hline D-Fructose & $\mathrm{w}$ & + & + & $\mathrm{ND}$ & $\mathrm{ND}$ \\
\hline D-Galactose & + & + & + & + & - \\
\hline myo-Inositol & - & + & - & + & - \\
\hline Maltose & + & + & + & + & - \\
\hline D-Mannitol & - & + & ND & + & + \\
\hline D-Mannose & - & + & + & + & - \\
\hline Melezitose & + & + & - & + & - \\
\hline D-Ribose & + & - & + & ND & ND \\
\hline D-Sorbitol & + & - & - & + & - \\
\hline Sucrose & + & + & - & + & - \\
\hline Trehalose & + & + & + & + & - \\
\hline D-Xylose & - & + & $\mathrm{w}$ & + & - \\
\hline \multicolumn{6}{|l|}{ Decomposition of: } \\
\hline Hypoxanthine & + & + & - & - & - \\
\hline Tyrosine & + & + & + & - & - \\
\hline \multicolumn{6}{|l|}{ Hydrolysis of: } \\
\hline Gelatin & - & - & $\mathrm{w}$ & - & - \\
\hline Starch & - & - & $\mathrm{w}$ & - & - \\
\hline Casein & - & + & + & - & - \\
\hline Urease activity & - & + & + & + & - \\
\hline Nitrate reduction to nitrite & - & - & + & - & + \\
\hline $\mathrm{H}_{2} \mathrm{~S}$ production & - & + & + & + & - \\
\hline Oxidation of ammonia & - & - & + & - & + \\
\hline \multicolumn{6}{|l|}{ Growth at/in: } \\
\hline $4{ }^{\circ} \mathrm{C}$ & - & + & $+^{*}$ & $-*$ & $+^{*}$ \\
\hline $37^{\circ} \mathrm{C}$ & $\mathrm{w}$ & + & $+^{*}$ & $+^{*}$ & $-{ }^{\star}$ \\
\hline $7 \% \mathrm{NaCl}$ & - & + & $+^{*}$ & $+^{*}$ & $-\star$ \\
\hline pH 9.0 & - & + & $-^{\star}$ & $+^{*}$ & 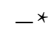 \\
\hline
\end{tabular}

${ }^{\star}$ Data from this study.

Strain YIM $56035^{\mathrm{T}}$ differed from its closest phylogenetic neighbour, P. kongjuensis DSM $44525^{\mathrm{T}}$, in several phenotypic properties, including acid production from some substrates, hydrolysis of casein, urease activity, $\mathrm{H}_{2} \mathrm{~S}$ production and growth at $4{ }^{\circ} \mathrm{C}, 7 \% \mathrm{NaCl}$ and $\mathrm{pH} 9.0$ (Table 2). The isolate is distinct from other the reference strains examined in most of the tested physiological properties (Table 2).

The genotypic and phenotypic data mentioned above show that strain YIM $56035^{\mathrm{T}}$ merits recognition as a novel 
species of the genus Pseudonocardia, for which the name Pseudonocardia endophytica sp. nov. is proposed.

\section{Description of Pseudonocardia endophytica sp. nov.}

Pseudonocardia endophytica (en.do.phy'ti.ca. Gr. endo within; Gr. phyton plant; L. fem. suff. -ica adjectival suffix used with the sense of belonging to; N.L. fem. adj. endophytica within plant, endophytic, pertaining to the original isolation from plant tissues).

Cells stain Gram-positive and are aerobic. Forms yellowish-brown substrate mycelium and white aerial mycelium on TSA and ISP2. The substrate mycelium fragments into rod-shaped elements. Spore chains form on aerial mycelium. No pigment is produced. Growth occurs at $15-37^{\circ} \mathrm{C}$, $\mathrm{pH} 6.0-8.0$ and $0-5 \% \mathrm{NaCl}$. Acid is produced from arbutin, aesculin, fructose, galactose, glucose, glycerol, maltose, melezitose, D-ribose, sucrose, salicin, sorbitol, trehalose and turanose, but not from adonitol, amygdalin, arabinose, arabitol, cellobiose, dulcitol, erythritol, fucose, gentiobiose, gluconate, glycogen, inositol, inulin, 2-ketogluconate, lactose, lyxose, mannitol, mannose, melibiose, methyl $\alpha$-glucoside, methyl $\alpha$-mannoside, methyl $\beta$-xyloside, $\mathrm{N}$-acetylglucosamine, raffinose, rhamnose, sorbose, starch, tagatose, xylitol or xylose. Utilizes L-asparagine, Lglutamic acid, $p$-hydroxyphenylacetic acid, $\alpha$-ketoglutaric acid, $\alpha$-ketovaleric acid, D-malic acid, $N$-acetyl-L-glutamic acid, propionic acid, putrescine, L-pyroglutamic acid, pyruvic acid, succinamic acid and succinic acid, but not acetic acid, L-alaninamide, D- or L-alanine, L-alanyl glycine, glycyl L-glutamic acid, $\alpha$-, $\beta$ - or $\gamma$-hydroxybutyric acid, lactamide, L-lactic acid, L-malic acid, methyl pyruvate, monomethyl succinate, pyruvic acid or L-serine. Ornithine decarboxylase and malonate tests give positive reactions; negative for nitrate reduction, milk peptonization and coagulation, gelatin liquefaction, growth in cellulose, gluconate test, $\mathrm{H}_{2} \mathrm{~S}$, melanin and urease production and starch hydrolysis. Catalase-positive and oxidase-negative. Other physiological properties are listed in Table 2. The cell-wall chemotype is type IV. The predominant menaquinone is MK- $8\left(\mathrm{H}_{4}\right)$. The phospholipids contain phosphatidylethanolamine, phosphatidylcholine, phosphatidylmethylethanolamine and diphosphatidylglycerol (phospholipid type PIII pattern). Major fatty acids are $\mathrm{i}-\mathrm{C}_{16: 0}, \mathrm{C}_{17: 1}$ cis 9 and $\mathrm{i}-\mathrm{C}_{15: 0}$. The DNA $\mathrm{G}+\mathrm{C}$ content of the type strain is $70.3 \mathrm{~mol} \%$.

The type strain, YIM $56035^{\mathrm{T}}\left(=\mathrm{DSM} 44969^{\mathrm{T}}=\right.$ CCTCC AA $206026^{\mathrm{T}}=$ KCTC $19150^{\mathrm{T}}$ ), was isolated from a plant sample collected from Xishuangbanna, Yunnan Province, south-western China.

\section{Acknowledgements}

The authors are very grateful to Dr J. P. Euzéby for his advice on nomenclature. This research was supported by the National Basic Research Program of China (project no. 2004CB719601), the Key Project of the Chinese Ministry of Education (no. 206139), the
National Natural Science Foundation of China (project no. 30560001, 30600001), the Yunnan Provincial International Cooperative Program (no. 2005GH21), the Ministry of Science and Technology, PR China (2006DFA33550), and the Korea Foundation for International Cooperation of Science \& Technology through a grant provided by the Korean Ministry of Education, Science and Technology in Global Partnership Program. W.-J. L. was supported by the Program for New Century Excellent Talents in University.

\section{References}

Christensen, H., Angen, Ø., Mutters, R., Olsen, J. E. \& Bisgaard, M. (2000). DNA-DNA hybridization determined in micro-wells using covalent attachment of DNA. Int J Syst Evol Microbiol 50, 1095-1102.

Collins, M. D. (1985). Isoprenoid quinone analysis in classification and identification. In Chemical Methods in Bacterial Systematics, pp. 267-287. Edited by M. Goodfellow \& D. E. Minnikin. London: Academic Press.

Collins, M. D. \& Jones, D. (1980). Lipids in the classification and identification of coryneform bacteria containing peptidoglycan based on 2, 4-diaminobutyric acid. J Appl Bacteriol 48, 459-470.

Coombs, J. T. \& Franco, C. M. (2003). Isolation and identification of actinobacteria from surface-sterilized wheat roots. Appl Environ Microbiol 69, 5603-5608.

Crawford, D. L., Lynch, J. M., Whipps, J. M. \& Ousley, M. A. (1993). Isolation and characterization of actinomycete antagonists of a fungal root pathogen. Appl Environ Microbiol 59, 3899-3905.

de Araújo, J. M., da Silva, A. C. \& Azevedo, J. L. (2000). Isolation of endophytic actinomycetes from roots and leaves of maize (Zea mays L.). Braz Arch Biol Technol 43 (4) doi: 10.1590/S1516-89132000000400016

Ezaki, T., Hashimoto, Y. \& Yabuuchi, E. (1989). Fluorometric deoxyribonucleic acid-deoxyribonucleic acid hybridization in microdilution wells as an alternative to membrane filter hybridization in which radioisotopes are used to determine genetic relatedness among bacterial strains. Int J Syst Bacteriol 39, 224-229.

Felsenstein, J. (1985). Confidence limits on phylogenies: an approach using the bootstrap. Evolution 39, 783-791.

Gordon, R. E., Barnett, D. A., Handerhan, J. E. \& Pang, C. H.-N. (1974). Norcardia coeliaca, Nocardia autotrophica, and the nocardin strain. Int J Syst Bacteriol 24, 54-63.

Groth, I., Schumann, P., Rainey, F. A., Martin, K., Schuetze, B. \& Augsten, K. (1997). Demetria terragena gen. nov., sp. nov., a new genus of actinomycetes isolated from compost soil. Int J Syst Bacteriol 47, 1129-1133.

Hasegawa, T., Takizawa, M. \& Tanida, S. (1983). A rapid analysis for chemical grouping of aerobic actinomycetes. J Gen Appl Microbiol 29, 319-322.

He, L., Li, W., Huang, Y., Wang, L. \& Liu, Z. (2005). Streptomyces jietaisiensis sp. nov., isolated from soil in northern China. Int J Syst Evol Microbiol 55, 1939-1944.

Henssen, A. (1957). Beiträge zur Morphologie und Systematic der thermophilen Actinomyceten. Arch Mikrobiol 26, 377-414 (in German).

Huang, Y., Wang, L., Lu, Z., Hong, L., Liu, Z., Tan, G. Y. A. \& Goodfellow, M. (2002). Proposal to combine the genera Actinobispora and Pseudonocardia in an emended genus Pseudonocardia, and description of Pseudonocardia zijingensis sp. nov. Int J Syst Evol Microbiol 52, 977-982.

Kumar, S., Tamura, K. \& Nei, M. (2004). MEGA3: integrated software for molecular evolutionary genetics analysis and sequence alignment. Brief Bioinform 5, 150-163. 
Lechevalier, M. P. \& Lechevalier, H. A. (1970). Chemical composition as a criterion in the classification of aerobic actinomycetes. Int J Syst Bacteriol 20, 435-443.

Lechevalier, H. A. \& Lechevalier, M. P. (1980). The chemotaxonomy of actinomycetes. In Actinomycete Taxonomy, Special Publication no. 6, pp. 277-284. Edited by A. Dietz \& D. W. Thayer. Arlington, VA: Society for Industrial Microbiology.

Lechevalier, M. P., De Bièvre, C. \& Lechevalier, H. A. (1977). Chemotaxonomy of aerobic actinomycetes: phospholipid composition. Biochem Syst Ecol 5, 249-260.

Lee, S. D., Kim, E. S., Min, K.-L., Lee, W. Y., Kang, S.-O. \& Hah, Y. C. (2001). Pseudonocardia kongjuensis sp. nov., isolated from a gold mine cave. Int J Syst Evol Microbiol 51, 1505-1510.

Li, W. J., Xu, P., Schumann, P., Zhang, Y. Q., Pukall, R., Xu, L. H., Stackebrandt, E. \& Jiang, C. L. (2007). Georgenia ruanii sp. nov., a novel actinobacterium isolated from forest soil in Yunnan (China) and emended description of the genus Georgenia. Int J Syst Evol Microbiol 57, 1424-1428.

Liu, Z. P., Wu, J. F., Liu, Z. H. \& Liu, S. J. (2006). Pseudonocardia ammonioxydans sp. nov., isolated from coastal sediment. Int J Syst Evol Microbiol 56, 555-558.

Martí, R., Cubero, J., Daza, A., Piquer, J., Salcedo, C. I., Morente, C. \& López, M. M. (1999). Evidence of migration and endophytic presence of Agrobacterium tumefaciens in rose plants. Eur J Plant Pathol 105, 39-50.

McVeigh, H. P., Munro, J. \& Embley, T. M. (1994). The phylogenetic position of Pseudoamycolata halophobica (Akimov et al. 1989) and a proposal to reclassify it as Pseudonocardia halophobica. Int J Syst Bacteriol 44, 300-302.

Mesbah, M., Premachandran, U. \& Whitman, W. B. (1989). Precise measurement of the $\mathrm{G}+\mathrm{C}$ content of deoxyribonucleic acid by highperformance liquid chromatography. Int J Syst Bacteriol 39, 159-167.

Minnikin, D. E., Collins, M. D. \& Goodfellow, M. (1979). Fatty acid and polar lipid composition in the classification of Cellulomonas, Oerskovia and related taxa. J Appl Microbiol 47, 87-95.

Okazaki, T., Takahashi, K., Kizuka, M. \& Enokita, R. (1995). Studies on actinomycetes isolated from plant leaves. Annu Rev Sankyo Res Lab 47, 97-106.
Prabahar, V., Dube, S., Reddy, G. S. N. \& Shivaji, S. (2004). Pseudonocardia antarctica sp. nov. an Actinomycetes from McMurdo Dry Valleys, Antarctica. Syst Appl Microbiol 27, 66-71.

Reichert, K., Lipski, A., Pradella, S., Stackebrandt, E. \& Altendorf, K. (1998). Pseudonocardia asaccharolytica sp. nov. and Pseudonocardia sulfidoxydans sp. nov., two new dimethyl disulfide-degrading actinomycetes and emended description of the genus Pseudonocardia. Int J Syst Bacteriol 48, 441-449.

Saitou, N. \& Nei, M. (1987). The neighbor-joining method: a new method for reconstructing phylogenetic tree. Mol Biol Evol 4, 406-425.

Sardi, P., Saracchi, M., Quaroni, S., Petrolini, B., Borgonovi, G. E. \& Merli, S. (1992). Isolation of endophytic Streptomyces strains from surface-sterilized roots. Appl Environ Microbiol 58, 2691-2693.

Sasser, M. (1990). Identification of bacteria by gas chromatography of cellular fatty acids, MIDI Technical Note 101. Newark, DE: MIDI Inc.

Shimizu, M., Nakagawa, Y., Sato, Y., Furumai, T., Igarashi, Y., Onaka, H., Yoshida, R. \& Kunoh, H. (2000). Studies on endophytic Actinomycetes (I): Streptomyces sp. isolated from rhododendron and its antifungal activity. J Gen Plant Pathol 66, 360-366.

Shirling, E. B. \& Gottlieb, D. (1966). Methods for characterization of Streptomyces species. Int J Syst Bacteriol 16, 313-340.

Stackebrandt, E. \& Goebel, B. M. (1994). Taxonomic note: a place for DNA-DNA reassociation and $16 \mathrm{~S}$ rRNA sequence analysis in the present species definition in bacteriology. Int J Syst Bacteriol 44, 846-849.

Strobel, G., Daisy, B., Castillo, U. \& Harper, J. (2004). Natural products from endophytic microorganisms. J Nat Prod 67, 257-268.

Thompson, J. D., Gibson, T. J., Plewniak, F., Jeanmougin, F. \& Higgins, D. G. (1997). The CLUSTAL_X windows interface: flexible strategies for multiple sequence alignment aided by quality analysis tools. Nucleic Acids Res 25, 4876-4882.

Waksman, S. A. (1961). Classification, identification, and description of genera and species. In The Actinomycetes, vol. 2, pp. 1-363. Baltimore: Williams \& Wilkins.

Warwick, S., Bowen, T., McVeigh, H. P. \& Embley, T. M. (1994). A phylogenetic analysis of the family Pseudonocardiaceae and the genera Actinokineospora and Saccharothrix with 16S rRNA sequences and a proposal to combine the genera Amycolata and Pseudonocardia in an emended genus Pseudonocardia. Int J Syst Bacteriol 44, 293-299. 